\title{
Explant Growth of Forage Palmcv Giant on Different Concentrations of Auxin and Cytokinin
}

\section{Luciana Cardoso NogueiraLonde ${ }^{1}$, Marcela Caroline Batista da Mota ${ }^{2}$, Selma Silva Rocha ${ }^{3}$, Júlio César Gomes Pereira ${ }^{3}$, Cintia Maria Teixeira Fialho ${ }^{4}$, Jéssica Guerra Calaes ${ }^{5}$}

\author{
${ }^{1}$ Empresa de PesquisaAgropecuária de Minas Gerais, Unidade Regional Epamig Norte de Minas. \\ Rodovia MGT 122, Km 155, Caixa Postal 12, CEP 39527-000 Nova Porteirinha, MG Brazil. \\ ${ }^{2}$ Universidade Federal dos Vales do Jequitinhonha e Mucuri, Diamantina - MG.Brazil. \\ ${ }^{3}$ Universidade Estadual de Montes Claros, Janaúba - MG. Brazil. \\ ${ }^{4}$ Universidade Federal de Viçosa, Viçosa - MG. Brazil. \\ ${ }^{5}$ Universidade Federal de Minas Gerais, Montes Claros - MG. Brazil. \\ ${ }^{1}$ luciana@epamig.br, ${ }^{2}$ mmmotacarol@gmail.com, ${ }^{3}$ selmauniagro@gmail.com, \\ 32Djocess10@hotmail.com, ${ }^{4}$ cintiamtfialho@yahoo.com.br, ${ }^{5}$ jessica_guerra_calaes@hotmail.com
}

\begin{abstract}
The forage palm is a good option for forage production in areas with water restriction. This kind of plant has great economic importance in several regions of Brazil; an alternative to increase production would be micropropagation technique, which enables rapid acquisition of a large number of plants with disease free in a short time and with high rates of genetic variability. This practice requires use of growth regulators, such as auxin, used to induce the development of nodes, callus formation and adventitious roots, and cytokinins regulate cell division of the aerial parts of the plant and promote the growth of lateral buds. Therefore, the aim of this study was to evaluate the development of explant of spineless cactus grow crops Giant (Opuntia ficus-indica Mill) established in vitro at different concentrations of naphthalene acetic acid (NAA) and 6-benzylaminopurine $(B A P)$. The experiment was conducted in a completely randomized design in a factorial scheme $6 x 6$ (ANA and $B A P)$. At 30 and 60 days were evaluated height, diameter, number of shoots and roots. The naphthalene acetic acid provided better results for height, diameter with a hormone dose in the range 1.5 to $2 \mathrm{mg} L-1$. As for BAP

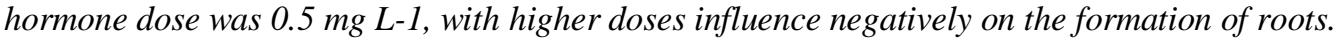

Keywords: Opuntia ficus-indica Mill, micropropagation, naphthalene acetic acid and 6-benzylaminopurine.

\section{INTRODUCTION}

In Brazil, the territorial area considered semi-arid covers an area of 980,133,079 $\mathrm{km}^{2}$, which represents $11.53 \%$ of Brazilian territory and $56.46 \%$ of the Northeast region (IBGE, 2010). This area constitutes the drought polygon (CODEVASF, 2011), which includes municipalities from all states of the Northeast, except Maranhão and also the North and Northeast of the state of Minas Gerais. Therefore, a cultivation alternative for this region is of a species that presents special physiological characteristics, as regards the absorption, recovery and loss of water.

The giant palm (Opuntia fícus-indica (L.) Mill) is used in animal and human feeding (MARTINS, 2011), endowed with physiological mechanisms that makes it one of the plants most adapted to the ecological conditions of the arid and semi-arid zones (SANTOS et al., 2006), in Minas Gerais, the crop is concentrated in the northern region of Minas Gerais.

Characteristics that make the palm an interesting option for these areas are linked to the impermeable cuticle, the smallest number of stomata and the photosynthetic apparatus. Plants with these characteristics are classified as CAM and have the capacity to capture solar energy during the day and fix $\mathrm{CO}_{2}$ at night, reducing water loss through evapotranspiration (RAMOS et al., 2011; SAMPAIO, 2005).

However, the limiting factor for animal production in this region is the inconstancy in the supply of food in quantity and quality in order to allow profitable livestock production (SALES et al., 2013). Therefore, a feeding alternative for ruminant farming is the forage palm $\mathrm{cv}$ giant, since it is a 
widespread species, adapted very well to the climatic phenomenon of the drought, being appropriate to situations of soil and temperatures unfavorable (SANTOS et al. , 2010).

According to REIS et al. (2009), in vitro plant cultivation has been an efficient technique, in addition to generating genetically identical plants, in a short period of time, they are free of infections and seasonal variations with high genetic variability. Being important for plants that cannot be improved by conventional methods.

This technique of growing small segments of plants (stem apices, buds, meristems, leaf fragments or roots) is carried out in specific containers containing suitable nutrient medium (ULISSES et al., 2010). In addition to this medium, it is necessary to supplement with phytoregulators, such as auxins, which are fundamental in the induction of cell division and induction of roots, and are also used in the multiplication stages to promote growth (MANTOVANI, FRANCO, 1998, BORGES et al., 2012 ). In addition, cytokinins are essential for cell division and multiplication, apical dominance, induction and proliferation of axillary buds and differentiation of adventitious buds (PREECE et al., 2011).

Therefore, this work was developed with the objective of investigating the growth of forage palm cv giant in different concentrations of auxins and cytokinins.

\section{Material AND Methods}

The experiment was conducted in the Plant Biotechnology Laboratory of the Empresa de PesquisaAgropecuária de Minas Gerais- EPAMIG Norte, in Nova Porteirinha, MG.

Initially, explants of the forage palm cv giant, from the EPAMIG field,were used as a source of biologic matherial for the subculture established in vitro after 60 days of introduction.

In the introduction, the cladodes were excised with $0.5 \mathrm{~cm}$ to obtain explants for in vitro culture. The palm explants were subsequently submitted to the disinfestation process, which consisted in immersion for 10 minutes in 0.2 g. $\mathrm{L}^{-1}$ streptomycin sulfate, 10 minutes in $0.3 \%$ Derosal fungicide and 5 minutes in $70 \%$ alcohol. Subsequently, a further immersion was carried out in 4.0 to $6.0 \% \mathrm{w} / \mathrm{v}$ sodium hypochlorite $(\mathrm{w} / \mathrm{v}$ ), followed by 7 minutes in $0.08 \%$ sodium $\mathrm{N}$-Dodecylbenzenesulfonate (Lysoform) and, subsequently, the triple lavage of the explants with distilled and autoclaved water was carried out.

The explants were introduced into MS culture medium (MURASHIGE; SKOOG, 1962), supplemented with $9 \%$ sucrose; $0.1 \mathrm{mg} . \mathrm{L}^{-1}$ inositol; $8 \mathrm{~g} . \mathrm{L}^{-1}$ agar for 60 days until the seedling stage. In this period of initial establishment, no phytoregulators were used for the development of the explant.

After this period, the seedlings formed were used for the experiment, in which the seedlings were subcultured to a pre-defined length of $0.5 \mathrm{~cm}$ and introduced into MS medium with $9 \%$ sucrose; 0.1 $\mathrm{mg} . \mathrm{L}^{-1}$ inositol at different concentrations of naphthalene acetic acid (NAA) $0.0 ; 0.5 ; 1,0 ; 1.5,2.0$ and $2.5 \mathrm{mg} . \mathrm{L}^{-1}$ and 6-benzylaminopurine (BAP) $0.0 ; 0.5 ; 1,0 ; 1.5 ; 2.0$ and $2.5 \mathrm{mg} . \mathrm{L}^{-1}$. The culture media was solidified with 8 g. $\mathrm{L}^{-1}$ agar. The $\mathrm{pH}$ of the medium was adjusted to $5.8 \pm 0.1$. The vials were sealed and autoclaved for 20 minutes at $120^{\circ} \mathrm{C}$.

The experiment was conducted in a completely randomized design in a factorial scheme (6X6). Totaling 36 treatments, with 4 replicates, 2 explants per replicate.

Subcultivated explants were sent to the growth room with artificial light at $25 \pm 1{ }^{\circ} \mathrm{C}$ under a photoperiod of $16 \mathrm{~h}$ light $(30 \mathrm{~W} / \mathrm{m} 2)$. After 30 days of implantation, the number of shoots, number of roots, height and diameter of the explants were evaluated. At 60 days, the same development parameters were evaluated.

The NAA and BAP doses were evaluated by regression analysis, using orthogonal polynomials, by the decomposition of the square sum of the interval in linear, quadratic and cubic effect. For all the conclusions it was considered $\alpha=0.05$, analyzing as sources of variation the doses of the mentioned hormones. For the number of shoots, the transformation was done, square root of $Y+0.5$, due to many repetitions with values 0 . The analysis of the development of the seedling was presented in the form of graphs.

\section{RESUlTS AND DiscuSSION}

For the evaluations performed at 30 days there was no interaction between the NAA and BAP factors. For the height characteristic there was a significant difference for the NAA factor $(p<0.05)$, for the diameter there was a significant difference also for the NAA factor ( $p<0.05)$, already for number of shoots and number of roots there was a significant difference For the BAP variation source $(\mathrm{p}<0.05)$ (TABLE 1). 
Explant Growth of Forage Palmcv Giant on Different Concentrations of Auxin and Cytokinin

Table 1. Summaryofvarianceanalysisoftheheight, diameter, numberofshootsand root number for theOpuntia ficus-indica (L.) Mill palmexplantsatthe 30-day evaluation.

\begin{tabular}{|c|c|c|c|c|c|}
\hline & & \multicolumn{4}{|l|}{ Mean Square } \\
\hline SourceofVariation & $\mathrm{DF}$ & Height $(\mathrm{cm})$ & Diameter $(\mathrm{cm})$ & Numberofshoots & Numberof roots \\
\hline NAA & 5 & $0,2895 *$ & $0,1777 *$ & $2,605 \mathrm{~ns}$ & $0,613 \mathrm{~ns}$ \\
\hline BAP & 5 & $0,0316 \mathrm{~ns}$ & $0,0334 \mathrm{~ns}$ & $9,803 *$ & $1,597 *$ \\
\hline NAA *BAP & 25 & $0,0554 \mathrm{~ns}$ & $0,0184 \mathrm{~ns}$ & $1,956 \mathrm{~ns}$ & $0,401 \mathrm{~ns}$ \\
\hline ERROR & 72 & $0,0413 \mathrm{~ns}$ & $0,026 \mathrm{~ns}$ & $1,328 \mathrm{~ns}$ & $0,379 \mathrm{~ns}$ \\
\hline
\end{tabular}

*, Ns = significantandnotsignificantat $5 \%$ byregressionanalysis, respectively.

When analyzing the NAA doses $\left(0.0,0.5,1.0,1.5,2.0\right.$ and $\left.2.5 \mathrm{mg} . \mathrm{L}^{-1}\right)$ presented in this study, it is observed that with the increase of this phytoregulator. There is an increase in height, as can be observed in figure 1 . Thus, the $2.5 \mathrm{mg} \cdot \mathrm{L}^{-1}$ dose was the one that presented the best result in relation to the other treatments, increasing the explant height by $1,70 \mathrm{~cm}$.

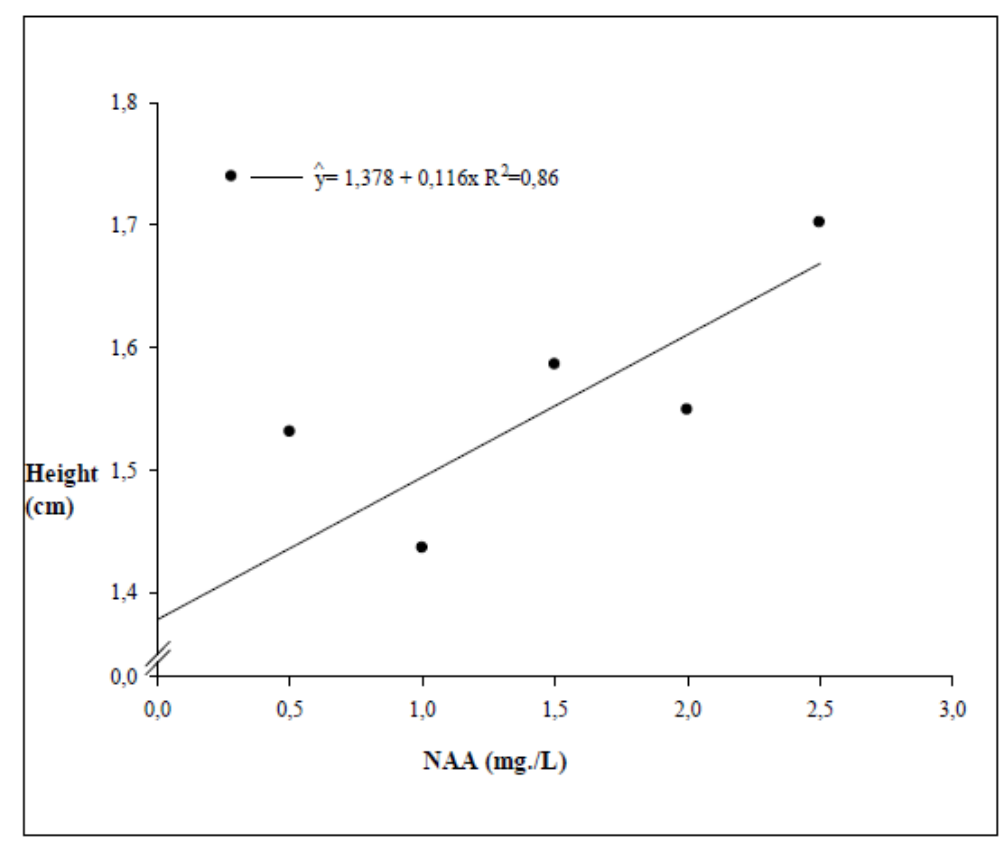

Figure1. Height of Opuntia ficus-indica (L.) Mill palmex plants at 30 days according to the different doses of naphthalene aceticacid (NAA).

Authors such as PASQUAL \& HOSHIKA (1992) observed a tendency to inhibit root development at higher concentrations of NAA, as was observed in the Gynmnocaliciumbuldiamur cactus species. In the present study, concentrations greater than $2 \mathrm{mg} . \mathrm{L}^{-1}$ of NAA caused an inhibitory effect on the development of shoots and diameter, since this hormonal concentration progressively inhibited the formation of these characteristics as the hormonal doses increased.

SOUTO et al. (2010) showed one working with Cattleya bicolorLindl. (Orchidaceae) and the effect of NAA on root length during the first 180 days, which made it evident that the $2 \mathrm{mg} . \mathrm{L}^{-1}$ concentration of this auxin significantly stimulated the growth of this organ. However, according to PERES and KERBAUY (2008), when auxin is applied in supra-optimal concentration, it has a marked effect on the inhibition of growth of vegetative organs.

In relation to the characteristic diameter there was only significant difference in the seedling $(p<0.05)$ for the ANA factor.

For this parameter there was a quadratic response to the treatments used. It is observed that $1.5 \mathrm{mg} . \mathrm{L}^{-1}$ of NAA provided a diameter of $0.60 \mathrm{~cm}$, increasing the concentration of auxin there was decrease of the response to the diameter of the seedlings.

For the sprouting characteristic, there was only a significant difference $(\mathrm{p}<0.05)$ for the BAP factor.

As the concentration of BAP was outstanding in relation to the other NAA phytoregulator, an inhibition of apical dominance occurs, resulting in the growth of shoots from axillary buds that are intensified with addition of cytokinins in the culture medium (FLORES et al., 2009). 


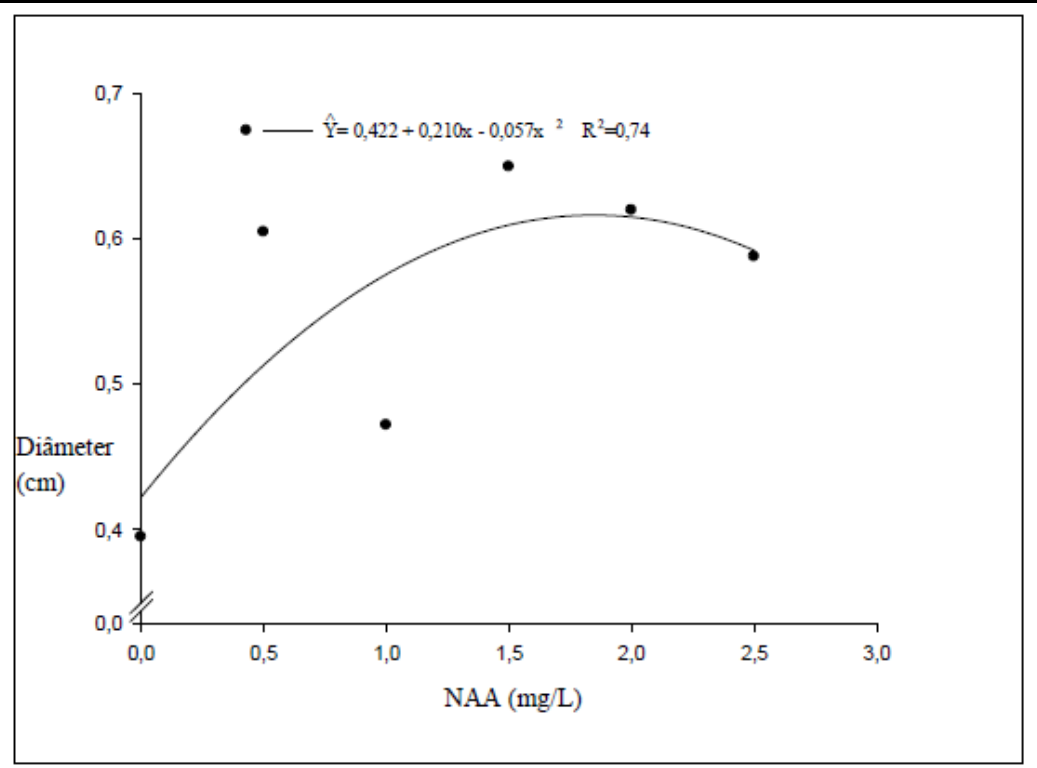

Figure 2. Diameters of Opuntia fícus-indica (L.) Mill palmexplantsat 30 days according to the different doses of naphthaleneaceticacid (NAA).

At 30 days the number of shoots showed a quadratic behavior, Figure 3 . It is observed that the increase in BAP concentration implies an increase in the number of shoots ( 2 shoots), where it was possible to obtain through an optimum hormonal concentration of $1.5 \mathrm{mg} . \mathrm{L}^{-1}$.

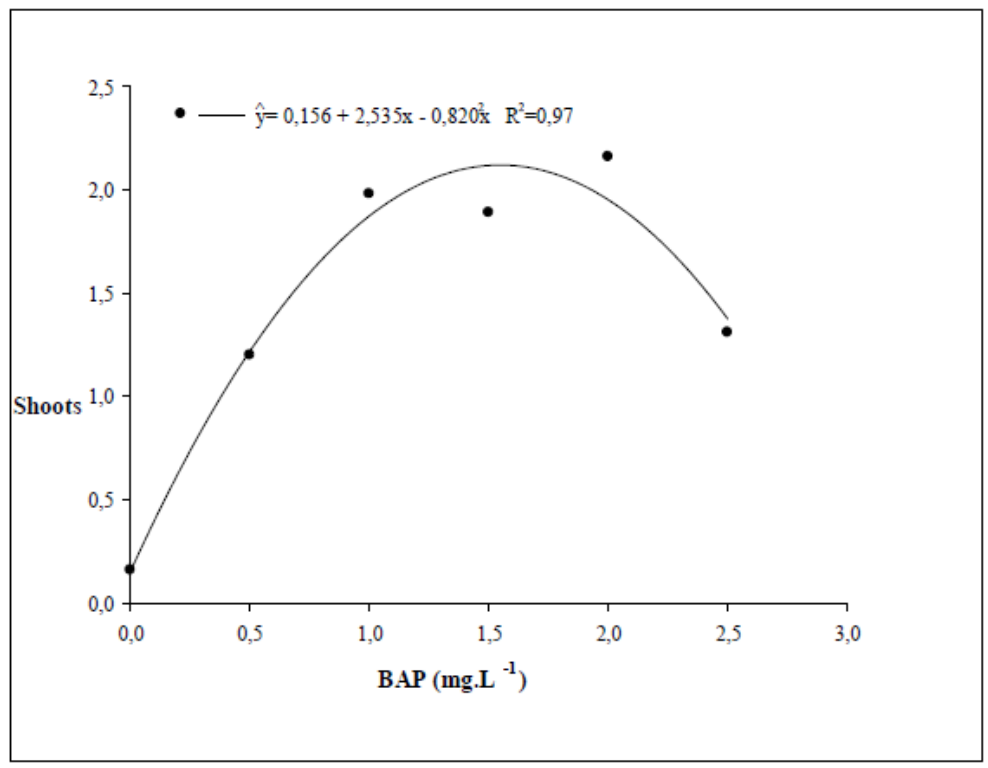

Figure 3. Shoots explants of Opuntia fícus-indica (L.) Mill at 30 days according to the different doses of 6 benzylaminopurine $(B A P)$

However, after this concentration considered optimal there is a decline in the number of shoots as the hormonal dose increases. The cytokinin stimulates the highest aerial part production of shoots up to a certain concentration, after which there is a phytotoxic effect caused by excess of the hormone (REIS, et al., 2008). Similar results were found by QUIALA et al. (2009), when they observed that the growth of $P$. robinii (Cactaceae) shoots was reduced with the increase of BAP concentration in the culture medium.

Similar results to these authors occurred in this study, where high levels of BAP inhibited shoot growth in the seedlings (Figure 3).

Regarding the number of roots, the significant difference in the seedling $(\mathrm{p}<0.05)$ occurred for the BAP factor.

Observing this characteristic in the seedling at 30 days, the absence of the BAP phytoregulator caused a greater induction of the number of roots ( 0.7 roots). 


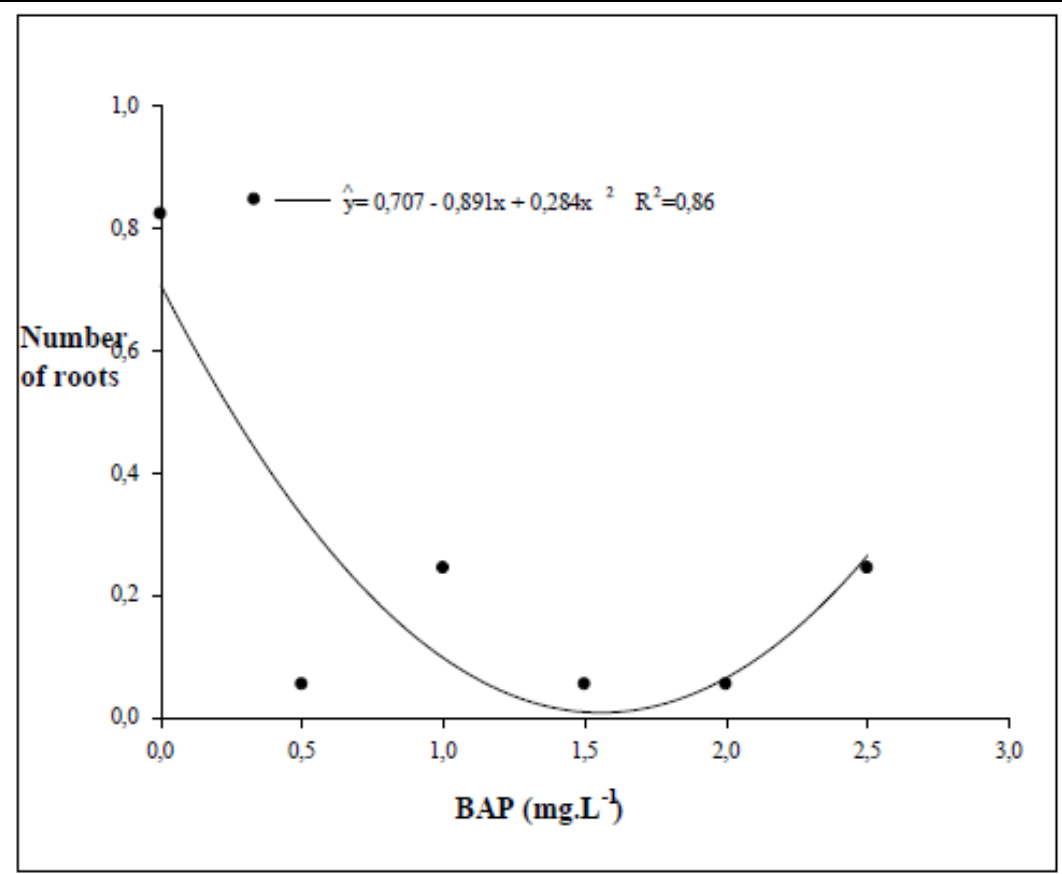

Figure 4. Number of roots of Opuntia ficus-indica (L.) Mill palm explants at 30 days according to the different doses of 6-benzylaminopurine (BAP)

Work related to this assert that moderate doses or high levels of cytokinins, are related to the production of shoots and not induction of roots. RESENDE (2010) working with species of the cactaceae family in vitro, observed that when these seedlings have satisfactory levels of endogenous auxin, they allow the induction of adventitious roots even in the absence of synthetic auxins. However, biochemical analyzes should be performed to confirm such a claim.

Thus, when the objective is in vitro rooting, the culture medium must be supplemented with auxins, which have the direct effect of inducing the formation of adventitious roots in these conditions of cultivation (SOUZA; PEREIRA, 2007).

FLORES et al. (2009) observed that in the in vitro propagation of Pfaffiaglomerata a higher percentage of rooting was observed in the shoots grown in MS medium without cytokinin. While in the presence of BAP there was a significant reduction in shoot rooting.

Similar results were obtained by MACHADO et al. (2006) who, working with the in vitro multiplication of 'VR043-43' grapevine, where they observed that different concentrations of BAP tested reduced the formation of roots. These assertions are confirmed by the results of this research, because when using higher concentrations of BAP, at 30 days, showed inhibitory effect on the number of roots.

After 60 days new evaluations of seedling development were made, where the same characteristics were evaluated: number of shoots, number of roots, height and diameter of the explants.

For the height characteristic there was a significant difference between NAA and BAP ( $p<0.05)$, for diameter there was a significant difference for NAA and BAP factors, but when there was no interaction, $(\mathrm{p}<0.05)$, already for number $(\mathrm{P}<0.05)$ and in relation to the number of roots there was no significant difference between the phytoregulators at this stage of the experiment (table 2).

Table 2.Summaryofvarianceanalysisofheight, diameter, numberofshootsand root number for Opuntia fícusindica palmexplantsat 60 daysofevaluation

\begin{tabular}{|c|c|c|c|c|c|}
\hline & & \multicolumn{4}{|c|}{ MEANS SQUARE } \\
\hline SourceofVariation & DF & Height $(\mathrm{cm})$ & Diameter $(\mathrm{cm})$ & Numberofshoots & Numberof roots \\
\hline NAA & 5 & $0,8659 \mathrm{~ns}$ & $0,3569 *$ & $4,7755 \mathrm{~ns}$ & $4,2833 \mathrm{~ns}$ \\
\hline BAP & 5 & $0,8243 \mathrm{~ns}$ & $0,1282 *$ & $9,3461 *$ & $4,3277 \mathrm{~ns}$ \\
\hline NAA*BAP & 25 & $0,5689 *$ & $0,0468 \mathrm{~ns}$ & $3,327 \mathrm{~ns}$ & $2,7944 \mathrm{~ns}$ \\
\hline ERRO & 72 & $0,2389 \mathrm{~ns}$ & $0,0493 \mathrm{~ns}$ & $2,0908 \mathrm{~ns}$ & $3,3888 \mathrm{~ns}$ \\
\hline
\end{tabular}

*, Ns = significantandnotsignificantat $5 \%$ byregressionanalysis, respectively. 
When analyzing height, the source of variation that presented significant difference was the interaction of the NAA * BAP phytoregulators, as described in table 2, but the result generated was not enough to create a statistical model.

For the characteristic diameter there was a significant difference $(\mathrm{p}<0.05)$ for NAA and BAP when analyzed separately in the seedling.

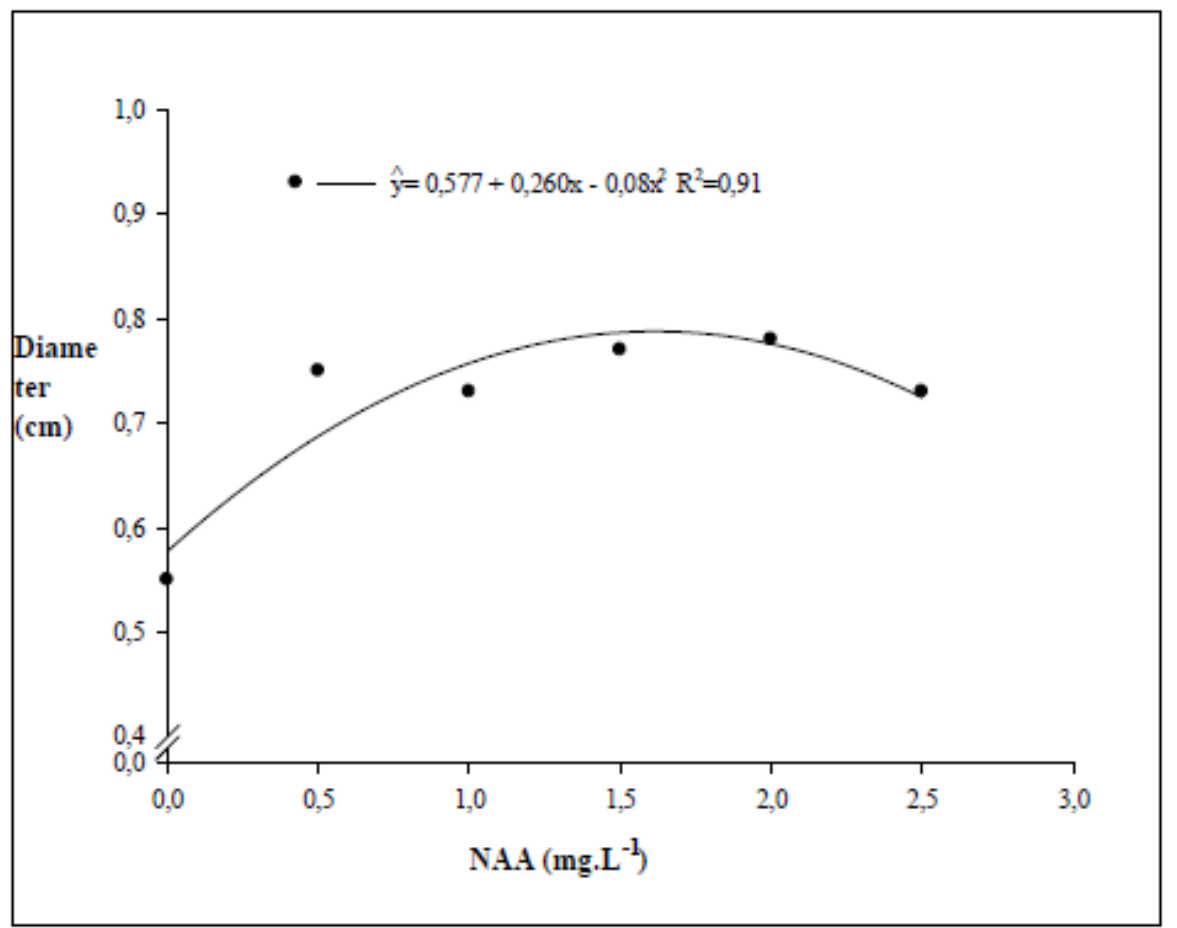

Figure5.Opuntia ficus-indica (L.) Mill palmexplants diameter at 60 days according to the different doses of naphthaleneaceticacid (NAA)

For the NAA factor, the concentration that presented the best result was $0.80 \mathrm{~cm}$ in diameter with an NAA concentration of $1.5 \mathrm{mg} . \mathrm{L}^{-1}$, after this point there is a decrease of the response with the increase of the hormonal concentration, as can be observed in figure 5 .

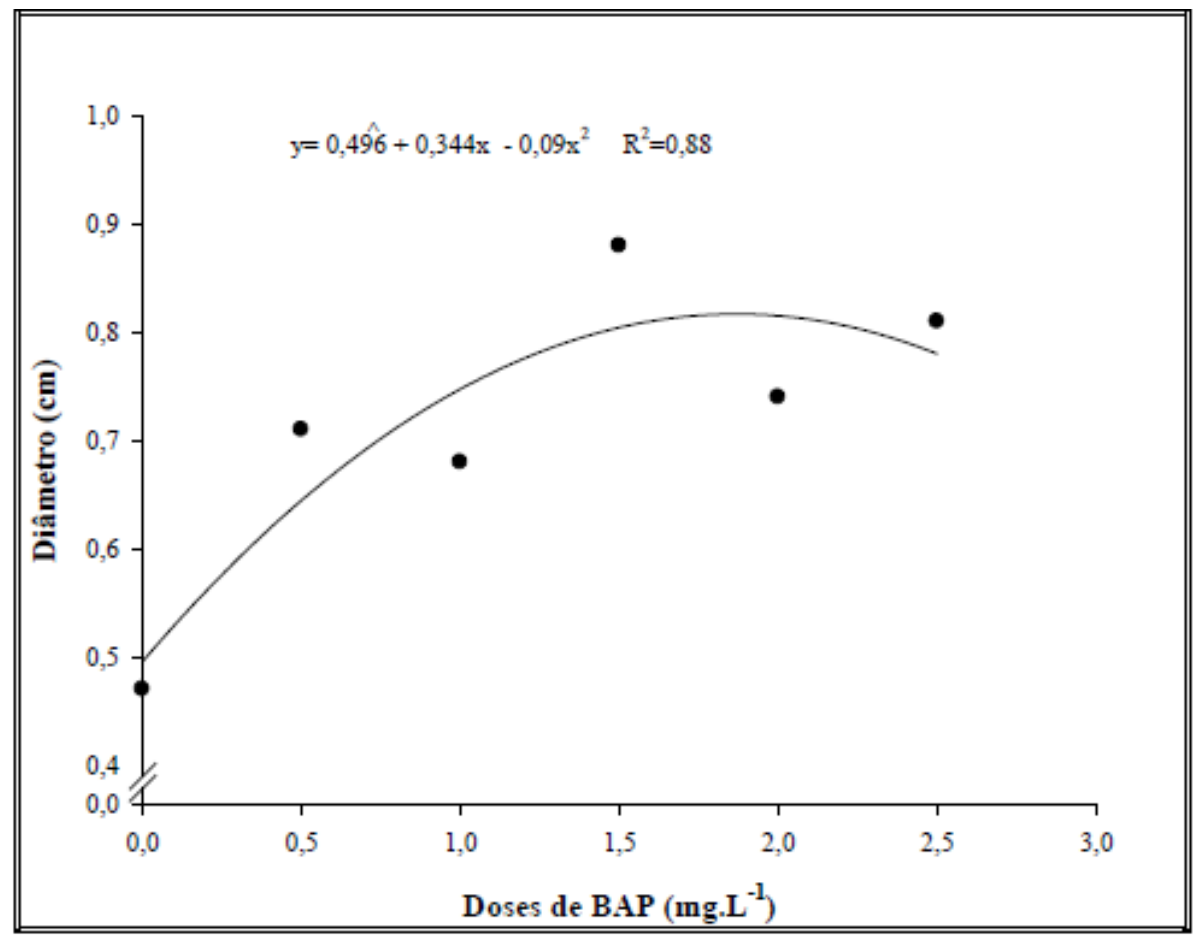

Figure 6.Opuntia ficus-indica (L.) Mill palm explants diameter at 60 days according to the different doses of 6benzylaminopurine (BAP) 
For BAP the ideal hormonal dose was $1.75 \mathrm{mg} . \mathrm{L}^{-1}$, where the explant presented a diameter of 0.80 $\mathrm{cm}$. After this point there is also a decrease in explant response with increased hormone concentration, figure 6 .

When analyzing number of shoots, the source of variation BAP was the one that presented a significant difference in relation to the other treatments, table 2, but the result generated was not enough to create a statistical model.

In relation to the number of roots there was no significant difference between the hormonal doses, as seen in table 2. Thus, it was not possible to analyze this characteristic.

\section{CONClusion}

- The results obtained in this study indicate that the cultivation of the palm cv. giant (Opuntia fícusindica (L.) Mill) caused different behaviors of the analyzed variables, height, diameter, number of shoots and number of roots at 30 and 60 days according to the hormones applied.

- In the MS culture medium the better hormonal dose of naphthalene acetic acid (NAA) would be in the range of 1.5 to $2 \mathrm{mg} . \mathrm{L}^{-1}$, since larger doses caused a reduction in the height and diameter of the explants.

- For the 6-benzylaminopurine (BAP) the hormonal dose would be $0.5 \mathrm{mg} . \mathrm{L}^{-1}$, since larger doses have a negative influence on root formation.

- For economics in the production system, it is recommended to use the concentration of $1.5 \mathrm{mg} . \mathrm{L}^{-}$ 1 of ANA.

\section{ACKNOWLEDGMENTS}

The authors thank the Fundação de Amparo à Pesquisa de Minas Gerais (FAPEMIG - Brazil).

\section{REFERENCES}

[1] BIST, R. et al. In vitro propagation of Aconitum balfouriiStapf: a rare medicinal herb of the alpine Himalayas. Indian Journal of Horticulture, Lucknow, v. 68, n. 3, p. 394-398, Aug. 2011.

[2] BORGES, S.R.; XAVIER, A.; OLIVEIRA, L.S.; LOPES, A.P.; OTONI, W.C.; TAKAHASHI, E.K.; MELO, L.A. Estabelecimentoin vitro de clones híbridos de Eucalyptus globulus. Ciência Florestal, Santa Maria, v. 22, n. 3, p. 605-616, set., 2012.

[3] CODEVASF. Companhia de desenvolvimento dos vales do São Francisco e Vale do Parnaíba. Polígono das secas. Disponível em: <http://www.codevasf.gov.br /osvales/vale-do-saofrancisco/poligono-das-secas > Acesso em 09/08/2016

[4] FLORES, R.; NICOLOSO, F. T.; MALDANER, J.; GARLET, T. M. Benzilaminopurina (BAP ) e thidiazuron ( TDZ ) na propagação in vitro de Pfaffiaglomerata( Spreng .) Pedersen. Revista Brasileira de PlantasMedicinais, Botucatu, v. 11, n. 3, p. 292-299, 2009.

[5] INSTITUTO BRASILEIRO DE GEOGRAFIA E ESTATÍSTICA (IBGE). Censo demográfico. Rio de Janeiro: IBGE, 2010.

[6] MACHADO, M.P.; BIASI, L.A.; RITTER, M.; RIBAS, L.L.F.; KOEHLER, H.S. Multiplicação in vitro do porta-enxerto de videira VR043-43 (Vitisvinifera X Vitisrotundifolia). Ciência e Agrotecnologia, Lavras, v.30, n.4, p.648-655, jul./ago. 2006.

[7] MANTOVANI, N. C.; FRANCO, E. T. H. Cultura de tecidos de plantas lenhosas. Santa Maria: UFSM, 1998. 132p.

[8] MARTINS, S.C.C. Avaliação do potencial biológico de Opuntia fícus-indica (Figueira da Índia). 2011, 67p. Dissertação (Mestrado em Ciências Farmacêuticas), Universidade Fernando Pessoa, Porto, 2011.

[9] MINISTÉRIO DA INTEGRAÇÃO NACIONAL - MI. Relatório final, grupo de trabalho interministerial para redelimitação do Semi Árido nordestino e do polígono das secas. Brasília, DF. 118p. 2005.

[10] PASQUAL, M. \& HOSHIKA, E. 1992. Efeitos do ácido naftaleno acético e 6-305 benzilaminopurina sobre a proliferação in vitro de cactos GynmnocaliciumbuldiamurL. e 306 MammillariabocasanaL. Pesquisa Agropecuária Brasileira, 24: 589-593. 
[11] PREECE, J. E. Can nutrient salts partially substitute for plant growth regulator? Plant Cell Culture and Biotechnology, Rehovot, v. 1, n. 1, p.26-37, 1995.

[12] PERES, L.E.P; KERBAUY, G.B. 2008. Citocininas. In: KERBAUY, G.B. Fisiologia Vegetal. Ed: Guanabara Koogan, Rio de Janeiro-RJ. p.:250-278.

[13] QUIAlA, E.; MATOS, J.; MONTALVO, G.; FERIA, M.; CHÁVEZ, M.; CAPOTE, A.; PÉREZ, N.; BARBÓN, R.; KOWALSKI, B. In vitro propagationofPilosocereusrobinii (Lemaire) Byles et Rowley, endemicandendangeredcactus. Journal of the Professional Association for Cactus Development, [Atkinsons], n. 11, p. 18-25, 2009.

[14] RAMOS, J. P. de F.; LEITE, M. L. de M. V.; OLIVEIRA JUNIOR, S. de; NASCIMENTO, J. P. do; SANTOS, E. M. Crescimento vegetativo de Opuntia fícus-indica em diferentes espaçamentos de plantio. Revista Caatinga, Mossoró, v. 24, n. 3, p. 41-48, 2011.

[15] REIS, E. S.; PINTO, J. E. B. P.; ROSADO, L. D. S.; CORRÊA, R. M. Influência do meio de cultura na germinação de sementes in vitro e taxa de multiplicação de Melissa officinalis L. Revista Ceres, Viçosa, v.55, n. 1, p.160-7, 2008.

[16] REIS, E. S.; PINTO, J. E. B. P.; SILVA ROSADO, L. D.; CORRÊA, R. M. Teor e composição química do óleo essencial de Melissa officinalisL. in vitro sob influência do meio de cultura. Acta Scientiarum. Agronomy, Maringá, v. 31, n. 2, p. 331-335, maio 2009.

[17] RESENDE, S. V. Micropropagação e conservação in vitro de MelocactusglaucescensBuining e Brederoo e M. paucispinus G. Heimen e R. Paul (Cactaceae), espécies endêmicas da Bahia e ameaçadas de extinção. 2010. 139 f. Tese (Doutorado em Botânica) - Universidade Estadual de Feira de Santana, Feira de Santana.

[18] SALES, A. T.; LEITE, M. L. M. V.; ALVES, A. Q.; RAMOS, J. P. F.; NASCIMENTO, J. P. Crescimento vegetativo de palma forrageira em diferentes densidades de plantio no Curimatú Paraibano. Tecnologia \& Ciência Agropecuária, v. 7, n. 1, p. 19 - 24, 2013.

[19] SAMPAIO, E. V. S. B. Fisiologia da palma In: MENEZES, R. S. C.; SIMÕES, D. A.; SAMPAIO, E. V. S. B. (Ed.). A palma no Nordeste do Brasil: conhecimento atual e novas perspectivas de uso. Recife: Ed. Universitária da UFPE, 2005. p. 43-56.

[20] SANTOS, D. C.; FARIAS, I.; LIRA, M. de A. et al. Manejo e utilização da palma forrageira (Opuntia e Nopalea) em Pernambuco. Pesquisa Agropecuária Brasileira. Documentos, 30. 48p, 2006 .

[21] SANTOS, M V. F.; LIRA, M. A.; DUBEUX JR, J.C.B. et al. Palma forrageira In: Plantas forrageiras. 1 ed.,Viçosa: Editora UFV, v.unico, p. 459-493. 2010b.

[22] SOUTO, J. S.; MORIMOTO, J. M.; FERREIRA, W. M.; NAKABASHI, M; SUZUKI, R. M. Efeitos do ácido naftalenoacético no desenvolvimento in vitro de Cattleya bicolor Lindl. (Orchidaceae). Revista Brasileira de Biociências, v. 8, n. 2, p. 179-185, 2010.

[23] SOUZA, A. V.; PEREIRA, A. M. S. Enraizamento de plantas cultivadas in vitro. Revista Brasileira de Plantas Medicinais, Botucatu, v. 9, n. 4, p. 103-117, 2007.

[24] UliSseS, C.; WILladinO, L.; AlBUQUERQUE, C. C. de; CÂMARA, T. R. Clonagem vegetal. Anais da Academia Pernambucana de Ciência Agronômica, Recife, v. 7, p. 86-91, 2010. 